\title{
Preoperative Evaluation of Lymph Node Metastases in Patients with Gastric Cancer: An Analysis of Imaging Methods
}

\section{Mide Kanseri olan Hastalarda Preoperatif Lenf Nodu Metastazının Değerlendirilmesi: Görüntüleme Yöntemlerin Analizi}

\author{
Yusuf Günay $^{1}$, Emrah Çağlar ${ }^{2}$, Esin Korkmaz ${ }^{3}$, Rabiye Uslu Erdemir ${ }^{4}$, İlhan Taşdöven ${ }^{1}$, \\ Ramazan Kozan ${ }^{1}$ \\ ${ }^{1}$ Department of General Surgery, Bulent Ecevit Üniversity, Zonguldak, Turkey \\ ${ }^{2}$ Department of Radiology, Bulent Ecevit Üniversity, Zonguldak, Turkey \\ ${ }^{3}$ Department of Pathology, Bulent Ecevit Üniversity, Zonguldak, Turkey \\ ${ }^{4}$ Department of Nucleer Medicine, Bulent Ecevit Üniversity, Zonguldak, Turkey
}

\section{ÖZET}

GİRIŞ ve AMAÇ: Mide kanseri olan hastalarda ameliyat öncesi evrelendirme cerrahi tedavi için gereklidir. Ancak ameliyat öncesi lenf nodu (LN) değerlendirilmesinde tek başına yeterli olabilecek bir test bulunmamaktadır. $\mathrm{Bu}$ çalışmanın amacı mide kanseri olan hastalarda, ameliyat öncesi LN tutulumunun değerlendirilmesinde pozitron emisyon tomografisi (PET/BT) ile bilgisayarlı tomografinin (BT) tanısal değerlerinin karşılaştırılmasıdır.

YÖNTEM ve GEREÇLER: Geriye dönük olarak gastrektomi ve D2 LN diseksiyonu ameliyatı olan seksen yedi hastanın değerlendirlmesidir. Görüntüleme yöntemleri ve patoloji raporları hasta dosyalarında toplandı. BULGULAR: PET/BT ile BT arasında mide kanseri olan hastalarda LN tutulumun kestirim gücü arasında anlamlı bir fark bulunmadı (p>0.05). PET/BT'nin LN nodunu öngerme duyarlılığı, özgüllüğü, pozitif kestirim değeri (PKD) ve negatif kestirim değeri (NKD) ile doğruluk değeri \%55.56, \%54.55, \%55.26, \%75 ve \%33.3 olarak hesaplanırken BT için \% 57.69, \%59.42, \%70.27, and \%46.88 olarak bulundu. Ancak, hem PET/BT ve BT birlikte kullanıldığında ameliyat öncesi mide kanseri olan hastalardaki LN metastazı belirlemede özgüllük PKD \% 80 ve \% 88.9 olarak bulundu. Sonuçlarımıza göre hastaya veya tümöre ait herhangi bir özelliğin PET/BT veya BT'nin LN metastazı öngörme gücü üzerinde etkisi görülmedi.

TARTIŞMA ve SONUÇ: PET/BT ve BT’nin birlikte kullanılması özgüllüğü ve PKD’ni arttırmaktadır. Bu artış, mide kanseri olan hastalarında ameliyat öncesi LN metastazı belirmede doğruluk değerini her iki testin ayrı ayrı kullanılmasında daha yüksektir.

Anahtar Kelmeler: Mide kanseri, lenf nodu, bilgisayarlı tomografi, pozitron emisyon tomografi

\begin{abstract}
INTRODUCTION: Preoperative evaluation is necessary for the surgical treatment of gastric cancer (GC). Nonetheless, there is no single best diagnostic modality to predict lymph node metastases prior to surgery. The aim of this study was to analyze of the diagnostic utility of positron emission tomography-computed tomography (PET-CT) and CT for the preoperative evaluation of lymph node (LN) metastases in GC. METHODS: Eighty seven patients with a history of GC, who underwent gastrectomy and D2 LN dissection were investigated. Imaging test results and pathology reports were collected from the patients' charts. RESULTS: There was no statistical differences between PET/CT and CT scans in regard to predicting LN metastases in GC patients ( $\mathrm{p}>0.05$ ). The sensitivity, specificity, positive predictive value (PPV), negative predictive value (NPV), and accuracy of PET/CT scans in predicting LN metastases were 55.56\%, 54.55\%, $55.26 \%, 75 \%$, and $33.3 \%$, respectively, versus $60.47 \%, 57.69 \%, 59.42 \%, 70.27 \%$, and $46.88 \%$ for CT scans, respectively. However, combined PET/CT and CT showed better outcomes and specificity with a PPV of $80 \%$ and $88.9 \%$, respectively. No patients or tumor factors were found to increase the accuracy of LN metastasis prediction using either PET/CT or CT scans.

DISCUSSION AND CONCLUSION: The combination of CT and PET/CT scans increases the specificity and PPV. This increases the prediction accuracy of LN metastasis in GC patients compared to the use of each type of imaging modality alone.

Keywords: Gastric cancer, lymph node, computerized tomography, positron emmission tomography
\end{abstract}




\section{INTRODUCTION}

GC is still one of the main causes of death in the world (1). However, patient survival rates have been increasing in developed countries $(2,3,4)$. It is well-known that lymph node (LN) metastases is a crucial prognostic factor in patients with GC $(5,6)$. Thus, predicting LN status may help determine a patient's prognosis and develop a surgical plan. Surgery is still the only option for curing patients with nonmetastatic GC. LN resection decreases recurrence and increases survival rates in patients with GC (7). Therefore, preoperative LN staging is essential for planning the optimal surgical treatment for GC, including LN dissection.

Although computerized tomography (CT) is one of the most common imaging tests used in patients with GC to predict LN metastases for preoperative evaluations, its accuracy is limited by the size of the LNs. Therefore, CT has some limitations for predicting LN metastases before surgery (8). On the other hand, 18-fluorodeoxyglucose (FDG) positron emission tomography integrated with CT (PET-CT) is used to investigate $\mathrm{LN}$ metastases of non-GCs because of its high specificity $(9,10)$. The predictive value of $\mathrm{PET} / \mathrm{CT}$ for $\mathrm{LN}$ evaluation is dependent on the ability of primary tumors to uptake 18-FDG, the number of LN metastases, the size of the LNs, and the presence of inflammation in areas of the body. Therefore, the usefulness of PET/CT in evaluating LN metastases needs to be interpreted according to each type of malignant tumor $(11,12)$. Although, few studies have reported the preoperative value of PET/CT for $\mathrm{LN}$ in patient with GC $(13,14)$, the predictive value of PET/CT versus CT in predicting $\mathrm{LN}$ metastases in GC patients has yet to be examined.

The aim of this study was to analyze the accuracy of preoperative PET/CT versus $\mathrm{CT}$ in evaluating preoperative $\mathrm{LN}$ metastases in patients with GC.

\section{PATIENTS and METHODS}

Between June 2012 and December 2017, 158 patients underwent surgical treatment for GC.
Patients with non-adenocarcinomas, such as GISTs (Gastrointestinal stromal tumors), sarcomas, or distant metastases, were excluded. Of these patients, 97 had gastric adenocarcinoma with preoperative PET/CT and/or CT, but 10 patients' pathological reports were incomplete. Therefore, 87 patients were included. After obtaining approval from the hospital institutional review board, preoperative PET/CT and CT were reviewed retrospectively for evidence of primary GC and $\mathrm{LN}$ metastases. The imaging reports were compared to the pathological reports. The maximum standardized uptake values (SUV), tumor size, tumor location, tumor type, the number of LNs, and the tumor stage were retrieved from imaging reports. In addition to these data, each patient's age and gender were obtained from the charts.

\section{Statistical analysis}

Results were given as the means \pm standard deviations. Results were compared using the Student's $t$-test and the Mann-Whitney U test. A multivariate analysis was then performed to identify independent risk factors for $\mathrm{LN}$ metastasis. The prediction of $\mathrm{LN}$ metastasis was calculated using receiver operating characteristic (ROC) curve analysis. The compliance of PET/CT and CT with the pathological LN metastasis was determined using McNemar, Kappa coefficient, and diagnostic screening tests, such as those for sensitivity and specificity. The confidence interval (CI) was set at $95 \%$, and p-values were considered significant at a level of $<0.05$. Statistical analysis was performed using the Number Cruncher Statistical System (NCSS) 2007 Statistical Software (NCSS LLC, Kaysville, Utah, USA).

\section{RESULTS}

The data from 87 patients were analyzed. The mean age of the patients was $62.04 \pm 12.73$ (range: $32-84)$ years. Sixty-five $(67 \%)$ patients were male, and $32(33 \%)$ were female. Of the 87 patients, $51(58,6 \%)$ underwent total gastrectomy and D2 LN dissection, and 36 (41.4\%) had a subtotal gastrectomy and D2 LN dissection. 
Table 1: The results of histopathological data for mean number of LNs was $21.47 \pm 13.88$ (range: 87 patients.

\begin{tabular}{lll}
87 patients. & & \\
\hline Pathology results & Data & n $(\%)$ \\
\hline \hline Regional LN & N0 & $29(33,4)$ \\
& N1 & $11(12,6)$ \\
& N2 & $14(16,1)$ \\
& N3 & $1(1,2)$ \\
& N3a & $19(21,8)$ \\
& N3b & $10(11,5)$ \\
& Nx & $3(3,4)$ \\
\hline Primary tumor & T1a & $4(4,6)$ \\
& T1b & $7(8,0)$ \\
& T2 & $7(8,0)$ \\
& T3 & $39(44,8)$ \\
& T4 & $1(1,2)$ \\
& T4a & $25(28,8)$ \\
& T4b & $4(4,6)$ \\
\hline TNM stage & $1 \mathrm{a}$ & $8(9,2)$ \\
& $1 \mathrm{~b}$ & $10(11,5)$ \\
& 2 & $13(14,9)$ \\
& $3 \mathrm{a}$ & $9(10,3)$ \\
& $3 \mathrm{~b}$ & $8(9,2)$ \\
& 4 & $39(44,8)$ \\
\hline
\end{tabular}
1-71) for each patient, while the metastatic LN number was $5.95 \pm 7.88$ (range: 1-35).

$$
\text { A statistical analysis showed that there }
$$
was an association between the PET/CT results and pathological LN, and this was noted as 8.5\% (Kappa coefficient: 0.085). However, the correlation was not statistically significant $(\mathrm{p}=0.725$, Table 2). Of the 40 patients who underwent a preoperative PET/CT, 21 (52.5\%) displayed FDG uptake, which were considered as positive LNs, whereas in $18(45 \%)$ patients, the LNs did not take up FDG and were considered as negative LNs. However, 14 of 21 patients (66.7\%) had experienced a pathological LN metastasis. Based on these results, the sensitivity, specificity, and accuracy of preoperative PET/CT for identifying LN metastases in gastric adenocarcinoma were $55.56 \%, 54.55 \%$, and $55.26 \%$, respectively. Moreover, the positive and negative predietive values of preoperative

A total of $40(41.2 \%)$ patients had a preoperative PET/CT, but only $22(55 \%)$ displayed FDG uptake in LNs. The mean number of PET/CT-positive LNs was $4.45 \pm 2.65$ (range: $1-10$ ). Of these $22 \mathrm{LNs}, 16$ $(72.2 \%)$ were in a perigastric location, while six $(27.3 \%)$ were at distant locations. The mean of the SUV max for the primary tumor was $9.93 \pm 7.83$ (range: $2.2-36$ ), whereas it was $6.14 \pm 3.52$ (range: $2.2-14.5$ ) for the LN. Of the $78(80.4 \%)$ patients with preoperative CT, 43 (55.1\%) had a positive LN. The mean short axis length for the LNs was $17.05 \pm 12.84$ (range: 2-60) $\mathrm{mm}$. The locations of positive LNs based upon the CT were $27(62.8 \%)$ in perigastric locations and $16(37.2 \%)$ were distant LNs. CT identified the primary tumor in $63(80.8 \%)$ patients. Of these GCs, 30 $(47.6 \%)$ were on the antrum, $21(33.3 \%)$ on the corpus, five $(7.9 \%)$ on the fundus, four $(6.4 \%)$ on the cardia, and three $(4.8 \%)$ were diffuse gastric tumors. The average size of the primary tumors identified by CT was 23.51 \pm 24.16 (range: 1-160) mm. Of the 87 adenocarcinoma types identified, $45(51.7 \%)$ were poorly differentiated, 36 (41.3\%) were moderately differentiated, and six (6.9\%) were welldifferentiated (Table 1). Of the 87 patients, 56 (64.4\%) had pathological LN metastasis. The
PET/CT scans to predict LN metastases in gastric adenocarcinoma patients were $75 \%$ and $33.3 \%$, respectively.

There was a statistical relation among the preoperative LN prediction of $\mathrm{CT}$ and pathological LN metastasis, and the level of compliance was found to be $17.4 \%$ (Kappa coefficient: 0.174). However, the correlation was not statistically significant $(\mathrm{p}=0.216$, Table 3). Of the 78 patients who underwent preoperative CT, $43(55.1 \%)$ had positive LNs identified by this method. However, histopathological examination identified metastatic LNs in 26 out of $43(60.4 \%)$ patients. Based on these results, it showed that the sensitivity, specificity, and accuracy of preoperative CTs in identifying LN metastases in gastric adenocarcinoma were $60.47 \%$, $57.69 \%$, and $59.42 \%$, respectively. Moreover, the positive predictive value (PPV) and negative predictive value (NPV) of preoperative $\mathrm{CT}$ scans in predicting $\mathrm{LN}$ metastases in GC were $70.27 \%$ and $46.88 \%$, respectively. Of the 87 patients, 23 (26.4\%) underwent both preoperative PET/CT and CT scans. In 23 patients, eight $(34.8 \%)$ had inconsistent results for the prediction of $\mathrm{LN}$ metastases between PET/CT and CT. 
Table 2: A comparison of PET/CT-based prediction of LN metastases and histopathological findings.

\begin{tabular}{lllll}
\hline & $\begin{array}{l}\text { Pathological } \\
\text { LN (-) }\end{array}$ & Pathological & Total & p \\
\hline \hline PET/CT LN (-) & $\mathbf{6}(\mathbf{1 5 , 8 )}$ & $12(31,6)$ & $18(47,4)$ & $\mathbf{0 , 7 2 5}$ \\
PET/CT LN (+) & $5(13,2)$ & $\mathbf{1 5}(\mathbf{3 9 , 5})$ & $20(52,6)$ & \\
\hline Total & $11(28,9)$ & $27(71,1)$ & $38(100)$ & \\
\hline Sensitivity & $55,56 \%$ & & \\
Specificity & $54,55 \%$ & & \\
Positive predictive value & $75,00 \%$ & & \\
Negativepredictive value & $33,33 \%$ & & \\
Accuracy & $55,26 \%$ & & & \\
\hline McNemar Test & & & &
\end{tabular}

Table 3: A comparison of CT prediction of LN metastases and histopathological findings.

\begin{tabular}{lllll} 
& Pathological & Pathological & Total & p \\
\hline \hline CT LN (-) & $\mathbf{1 5}(\mathbf{2 1 , 7 )}$ & $17(24,6)$ & $32(46,4)$ & $\mathbf{0 , 2 1 6}$ \\
CT LN (+) & $11(15,9)$ & $\mathbf{2 6}(\mathbf{3 7 , 7})$ & $37(53,6)$ & \\
\hline Total & $26(37,7)$ & $43(62,3)$ & $69(100)$ & \\
\hline Sensitivity & $60,47 \%$ & & \\
Specificity & $57,69 \%$ & & \\
Positive predictive value & $70,27 \%$ & & \\
Negativepredictive value & $46,88 \%$ & & \\
Accuracy & $59,42 \%$ & & & \\
\hline
\end{tabular}

McNemar Test

Table 4: ROC results. The value of PET/CT and CT for predicting preoperative LN metastases.

\begin{tabular}{|c|c|c|c|c|c|}
\hline \multicolumn{6}{|l|}{ Area Under the Curve } \\
\hline \multirow[b]{2}{*}{ Test Result Variable(s) } & \multirow[b]{2}{*}{ Area } & \multirow[b]{2}{*}{ Std. Error ${ }^{\mathbf{a}}$} & \multirow{2}{*}{$\begin{array}{l}\text { Asymptotic } \\
\text { Sig. }\end{array}$} & \multicolumn{2}{|c|}{$\begin{array}{l}\text { Asymptotic 95\% Confidence } \\
\text { Interval }\end{array}$} \\
\hline & & & & Lower Bound & Upper Bound \\
\hline PET/CT LN & 0,698 & 0,122 & 0,161 & 0,458 & 0,938 \\
\hline CT LN & 0,646 & 0,134 & 0,302 & 0,382 & 0,909 \\
\hline
\end{tabular}

Table 5: Logistic regression analysis of histopathological tumor types on pathological LN metastases.

\begin{tabular}{llllll}
\hline $\begin{array}{l}\text { Histopathological type of } \\
\text { tumor (differentiation) }\end{array}$ & $\mathbf{p}$ & ODDS & \multicolumn{2}{c}{ 95\% C.I.for ODDS } \\
Lower & Upper \\
\hline \hline Step 1a & Well & 0,068 & & & \\
\cline { 2 - 6 } & Moderately & 0,219 & 3,143 & 0,507 & 19,492 \\
\hline & Poorly & $0,038^{*}$ & 7,111 & 1,116 & 45,292 \\
\hline
\end{tabular}

$* p<0,05$

Table 6: Logistic regression analysis of tumor stage on pathological LN metastasis.

\begin{tabular}{|c|c|c|c|c|c|}
\hline \multirow{2}{*}{ T stage } & & \multirow[b]{2}{*}{ p } & \multirow{2}{*}{ ODDS } & \multicolumn{2}{|c|}{ 95\% C.I.for ODDS } \\
\hline & & & & Lower & Upper \\
\hline \multirow[t]{4}{*}{$\overline{\text { Step } 1^{a}}$} & $\overline{\mathrm{T} 1}$ & $0,002 * *$ & & & \\
\hline & $\mathbf{T 2}$ & 0,525 & 0,444 & 0,037 & 5,406 \\
\hline & $\mathbf{T 3}$ & $0,019 *$ & 6,000 & 1,351 & 26,649 \\
\hline & $\mathbf{T 4}$ & $0,002 * *$ & 13,333 & 2,592 & 68,589 \\
\hline
\end{tabular}


However, $18(78.3 \%)$ patients had consistent results between PET/CT and CT. Thus, the sensitivity, specificity, PPV, NPV, and accuracy in patients between PET/CT and CT were $61.5 \%, 80 \%, 88.9 \%, 44.4 \%$, and $66.7 \%$, respectively.

The ROC analysis revealed that the area under the curve for PET/CT was $69.8 \%$, and the standard deviation was $10.5 \%$. Meanwhile, the area under the curve and standard deviation were $64.6 \%$ and $12.3 \%$, respectively, for the CT scan (Figure 1) with regard to predicting preoperative $\mathrm{LN}$ metastases in GC. When these results were compared, there were no statistically significant differences in the preoperative prediction of LN metastasis between PET/CT and $\mathrm{CT}$ in any TNM stage $(\mathrm{p}=0.602$, Figure 1$)$.

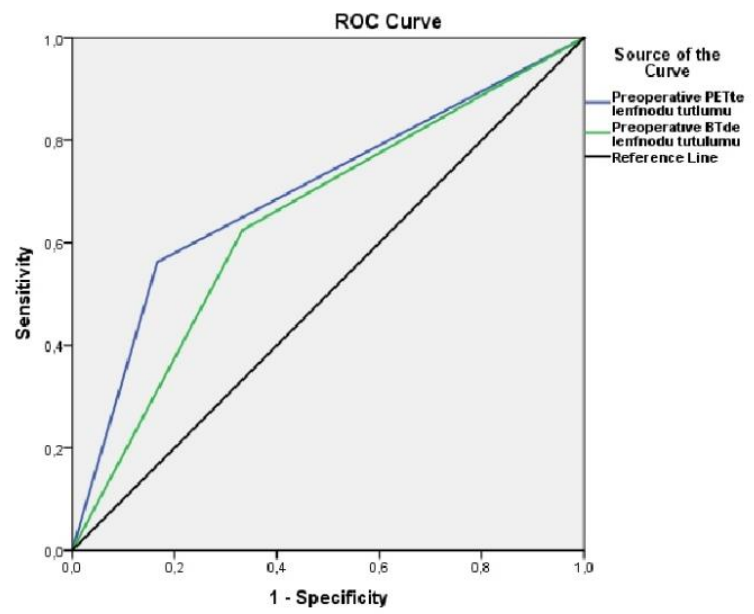

Figure 1. The area under curve for PET/CT in the analysis of ROC.

A multivariant logistic regression analysis was performed to determine the potential factors in assessing pathological LN metastases. The histological type of adenocarcinoma was found to be an independent risk factor for $\mathrm{LN}$ metastasis $(p<0.05)$. Poorly differentiated adenocarcinoma was a potential risk compared with well-differentiated tumors, and the risk was statistically significant (OR: 7.111, 95\% CI: $1.116-45.292, p<0.05)$. The risk for moderately differentiated adenocarcinoma compared to well-differentiated adenocarcinoma was higher, but not statistically significant $(\mathrm{p}=0.219$, Table 5$)$. The logistic regression analysis of tumor size in predicting preoperative LN metastases revealed that tumor size is an independent risk factor $(p<0.05$, Table 6$)$. By comparing T3 versus $\mathrm{T} 1$, the risk was found to be statistically significant (OR: 6.000, (95\% CI: 1.35126.649, $\mathrm{p}=0.019$ ). Meanwhile, the risk of T4 compared with $\mathrm{T} 1$ was statistically significant (OR: $13.3,95 \%$ CI: $2.59, \mathrm{p}<0.01$ ).

\section{DISCUSSION}

In spite of recent advances in diagnostic methods, the rate of inconsistency in preoperative and postoperative staging of GC still is high, and it is reported in one-third of patients $(15,16)$. The reasons for the inconsistency in staging in GC patients before surgery are either incomplete preoperative assessments or insufficient preoperative imaging methods. Inaccurate preoperative assessments may lead to ineffective treatments or unnecessary overtreatment (17). Thus, we analyzed the results of the two most common modalities used in evaluating preoperative GC staging. In this study, our data showed that neither PET/CT nor CT are the best imaging tests for predicting LN metastasis in GC patients as standard tests. In contrast, these techniques may help predict LN staging if used in combination.

One of the most common imaging tests used for preoperative $\mathrm{LN}$ assessments in GC patients is the CT scan. However, as previously reported in the literature (17), CT has many limitations, such as evaluating LN only based on size. Thus, evaluating preoperative LNs using CT does not allow a clinician to differentiate malignancy from reactive or infected LNs (17). Moreover, micro metastases of LNs are well-known, and it is very difficult to predict these using CT (18). Even though there was an association between preoperative CT and pathological findings in this study, the sensitivity, specificity, PPV, and NPV were not great enough to predict preoperative LN metastases in GC patients, and these results were consistent with a previous study (8). Also consistent with literature, this study did not reveal LN size or location to be independent factors that increase the sensitivity or specificity of CT in predicting LN metastases (17). Meanwhile, in contrast to previous reports, we did not find 
potential effects of $\mathrm{LN}$ staging, in predicting LN metastases using CT (19). Overall, our results showed that CT may not be the best imaging test to use when trying to predict preoperative LN metastases in GC patients as a standard test.

In contrast to $\mathrm{CT}, \mathrm{PET} / \mathrm{CT}$ identifies LN metastases based on metabolic activity, not on LN size. One of the advantages of PET/CT over CT is the ability to identify micrometastases in LNs. However, PET/CT has some disadvantages, such as the inability to discriminate metastases from infections or reactivity, which has been reported in the literature and confirmed in this study. We found that the greatest FDG uptake occurred in the perigastric area, which was most likely due to increased inflammation near the primary tumor. This is consistent with previous findings in the literature (20). In a multivariant and ROC analysis, it was revealed that the sensitivity of PET/CT was too low to predict $\mathrm{LN}$ metastases in GC patients, and this result is consistent with those in the literature (14). Moreover, this study did not reveal any effect of SUVmax or the number of LNs examined using PET/CT with regard to predicting LN metastases.

Although, the differences were not significant between PET/CT and CT in predicting LN metastases, our analysis showed that PET/CT has higher specificity and PPV, whereas CT has greater sensitivity. This is consistent with previous reports $(21,22,23,24)$. In this study, we also analyzed the results of patients having CT and PET/CT. Combined $\mathrm{CT}$ and PET/CT increases the specificity, PPV, and accuracy of predicting LN metastases in GC patients. Therefore, combining the use of $\mathrm{CT}$ and PET might be helpful in predicting LN metastases in GC patients compared to each technique alone.

Even though our results revealed that tumor type and size are two independent risk factors for $\mathrm{LN}$ metastases in GC patients, neither one was a factor that increases the sensitivity or specificity of predicting LN metastases using CT or PET/CT. Overall, this study did not identify any tumor or patientspecific factors that affected the capacity of PET/CT or CT to predict LN metastases, such as tumor location, subtotal versus total gastrectomy, patient's age, gender, or number of LNs. Since this study was related to the preoperative assessment of LN metastases, we did not evaluate postoperative outcomes or perform a patient survival analysis.

As limitation of this study, it is a retrospective study with limited inheritance. Second, this study had a small number of patients undergoing CT and PET/CT, and this may have resulted in a lower sensitivity compared to other studies in the literature $(25,26)$. Third, the number of CT and PET/CT scans were not the same between the experimental groups.

\section{CONCLUSION}

The sensitivity, specificity, PPV, and NPV of both CT and PET/CT were not high enough to predict LN metastases in GC patients when the techniques were used alone. However, the combination of CT and PET/CT scans yielded higher specificity and PPV, possibly increasing the ability to predict LN metastases in GC patients compared to the use of each imaging technique alone.

\section{Acknowledgment}

We would like to thank Emine Bor for her great assistance in statistics.

\section{REFERENCES}

1. Ferlay J, Soerjomataram I, Dikshit R, et al. Cancer incidence and mortality worldwide: sources, methods and major patterns in GLOBOCAN 2012. Int J Cancer. 2015;136(5):E359-86

2. Van Cutsem E, Sagaert X, Topal B, Haustermans K, Prenen H. Gastric cancer. Lancet. 2016;388:26542664.

3. Ahmad SA, Xia BT, Bailey CE, Abbott DE, et al. An update on gastric cancer. Curr Probl Surg. 2016;53: 449-490.

4. De Mestier L, Lardière-Deguelte S, Volet J, Kianmanesh R, Bouché O. Recent insights in the therapeutic management of patients with gastric cancer. Dig Liver Dis. 2016;48.984-994.

5. Siewert JR, Bottcher K, Stein HJ, Roder JD. Relevant prognostic factors in gastric cancer: tenyear results of the German gastric cancer study. Ann Surg. 1998;228:449-61.

6. Zhang XF, Huang CM, Lu HS, et al. Surgical treatment and prognosis of gastric cancer in 2,613 patients. World J Gastroenterol. 2004;10:3405-8.

7. Dudeja V, Habermann EB, Abraham A, et al. Is there a role for surgery with adequate nodal evaluation alone in gastric adenocarcinoma? J Gastrointest Surg (2012) 16(2):238-47. 
8. Kwee RM, Kwee TC. Imaging in local staging of gastric cancer: a systematic review. J Clin Oncol. 2007;25(15):2107-16.

9. Serrano OK, Love C, Goldman I, et al. The value of FDG-PET in the staging of gastric adenocarcinoma: a single institution retrospective review. J Surg Oncol. 2016;113(6):640-6.

10. Li P, Liu Q, Wang C, et al. Fluorine-18fluorodeoxyglucose positron emission tomography to evaluate recurrent gastric cancer after surgical resection: a systematic review and meta-analysis. Anna Nuclear Med. 2016;30(3):179-87.

11. Vansteenkiste J, Fischer BM, Dooms C, Mortensen J. Positron-emission tomography in prognostic and therapeutic assessment of lung cancer: systematic review. Lancet Oncol. 2004;5:531-540

12. Yun M, Lim JS, Noh SH, et al. Lymph node staging of gastric cancer using (18)F-FDG PET: a comparison study with CT. J Nucl Med. 2005 Oct;46(10):1582-8.)

13. Youn SH, Seo KW, Lee SH, Shin YM, Yoon KY. 18F-2-Deoxy-2-Fluoro-D-Glucose Positron Emission Tomography: Computed Tomography for Preoperative Staging in Gastric Cancer Patients. J Gastric Cancer. 2012;12:179-186.

14. Filik M, Kir KM, Aksel B, et al. The role of $18 \mathrm{~F}$ FDG PET/CT in the primary staging of gastric cancer. Mol Imaging Radionucl Ther. 2015;24:1520.

15. Hartgrink H.H, Jansen E.P, van Grieken N.C., van de Velde C.J. Gastric cancer. Lancet. 2009;374:477490.

16. Catalano V, Labianca R, Beretta G.D, Gatta G, de Braud F., Van Cutsem E. Gastric cancer. Crit. Rev. Oncol. Hematol. 2009;71:127-164.

17. Stabile Ianora AA, Telegrafo M, Lucarelli NM, Lorusso V, Scardapane A, Niccoli AsabellaA, MoschettaM.Comparison between CT N et enhancement and PET/CT SUV fr N staging of gastric cancer: A case series. Ann Med Surg (Lond). 2017 Jul 15;21:1-6.
18. Fukagawa T, Sasako M, Mann GB, et al. Immunohistochemically detected micrometastases of the lymph nodes in patients with gastric carcinoma. Cancer. 2001;92:753-60.

19. Yun M, Lim JS, Noh SH, et al. Lymph node staging of gastric cancer using (18)FFDG PET: a comparisonstudy with CT. J Nucl Med. 2005;46(10):1582-8

20. OkumuraY, AikouS, OnoyamaH, etal.Evaluation of 18FFDG uptake for detecting lymph node metastasis of gastriccancer:a prospective pilot study for onebto one comparison of radiation doseand pathological findings. World J Surg Oncol. 2015 Dec 2;13:327

21. Kim EY, Lee WJ, Choi D, et al. The value of PET/CT for preoperative staging of advanced gastric cancer: comparison with contrastenhanced CT. Eur J Radiol 2011;79:183-188.

22. Lim JS, Kim MJ, Yun MJ, et al. Comparison of CT and 18F-FDG PET for detecting peritoneal metastasis on the preoperativeevaluation for gastric carcinoma. Korean J Radiol 2006;7:249-256.

23. Kim SK, Kang KW, Lee JS, et al. Assessment of lymph node metastases using 18F-FDG PET in patients with advanced gastric cancer. Eur $\mathrm{J}$ Nucl Med Mol Imaging. 2006; 33(2): 148-155.

24. Yang QM, Kawamura $\mathrm{T}$, Itoh $\mathrm{H}$, et al. Is PET-CT suitable for predicting lymph node status for gastric cancer? Hepato-gastroenterology. 2008; 55(82-83): 782-785.

25. Seevaratnam R., Cardoso R., McGregor C., et al. How useful is preoperative imaging for tumor, node, metastasis (TNM) staging ofgastric cancer? A metaanalysis. Gastric Cancer. 2012;15(Suppl 1):S3-S18.

26. Altini C., Niccoli Asabella A., Di Palo A., et al. 18FFDG PET/CT role in staging of gastric carcinomas: comparison with conventional contrast enhancement computed tomography. Med. 